\title{
The Strength of Evidence (Certificate) in Land Rights Disputes According to Government Regulation No. 24 of 1997 Concerning Land Registration
}

\author{
Gabriella Talenta Sekotibo ${ }^{1 \otimes}$ \\ ${ }^{1}$ Faculty of Law, Universitas Surabaya, Indonesia \\ $\bowtie$ gabriellatalenta24@gmail.com
}

\begin{abstract}
The purpose of this study is to provide legal certainty and to resolve disputes over land rights ownership for buyers who are acting in good faith when purchasing and selling inheritance. The research method is normative juridical, employing both a statutory and case-based approach. According to the study's findings, buyers with good intentions receive legal protection in the form of compensation. However, when parties with bad intentions violate Article 1267 of the Civil Code, the legal consequences of buying and selling inherited land are null and void, as they contain elements of fraud, oversight, and ignorance. additional heirs. Keeping in mind that the property being traded is inheritance land that already possesses permanent legal standing and cannot be traded without the approval of other heirs.
\end{abstract}

Keywords: Legal Protection; Good Faith Buyers; and Inheritance Land.

\section{INTRODUCTION}

Land is one of the basic needs for humans, even to death humans still need land. Today, human needs for land are increasing. This is because the population is increasing while the land area remains constant. ${ }^{1}$ Land, in a legal sense, is the earth's surface; land rights are limited, twodimensional rights to a specific portion of the earth's surface. With the promulgation of Law No. 5 of 1960 on Fundamental Agrarian Principles, abbreviated as UUPA. The LoGA is a watershed moment in the development of Indonesia's land provisions, as it regulates various types of land rights. Among the various types of land rights, land ownership rights are the most powerful, comprehensive, and hereditary land rights that individuals can have on land, and only property rights are not subject to the state's validity period, in comparison to other land rights. ${ }^{2}$

In the UUPA, a person's land rights are also referred to as land tenure rights. Mastery is a term that can be used in a physical sense, a legal sense, as well as in private and public contexts. Control in the legal sense is control based on legally protected rights and generally entitles the

\footnotetext{
${ }^{1}$ M.P Siahan, Bea Perolehan Hak Atas Tanah dan Bangunan Teori dan Praktek, Raja Grafindo Persada, Jakarta, 2003, p 1

2 Redi Res, 'Implementation of Parate Executie Object of Liability Juridical Overview of Mortgage', 1.1 (2021), 42-53.
} 
DOI: https://doi.org/10.53955/ihcls.v1i2.12

Published by Lembaga Contrarius Indonesia

This work is licensed under a Creative Commons Attribution 4.0 International License (cc-by).

right holder to exercise physical control over land that has not been transferred to another party. There is also juridical control, which gives the authority to control land that has been physically acquired, but the physical control is actually exercised by another party. For example, if someone owns land but does not use it, but leases it to another party, the land is juridical. owned by the landowner but carried out physically by the land tenant There is also juridical control that does not entail physical control of the land in question; for example, creditors (banks) who hold collateral rights over land have juridical control over the land used as collateral (collateral), but physical control remains with the land owner. ${ }^{3}$

The UUPA is a mandate for the implementation of Article 33 paragraph (3) of the 1945 Constitution of the Republic of Indonesia (hereinafter referred to as the 1945 Constitution), which states that the earth, water, and natural resources contained therein are to be controlled by the State and used for the greatest prosperity of the people, as specified in Article 19 of the 1945 Constitution. Government Regulation No. 24 of 1997 implements UUPA regulation of land registration. According to Government Regulation No. 24 of 1997 on Land Registration, land registration is a series of activities carried out by the government continuously, continuously, and regularly, including the collection, processing, bookkeeping, presentation, and maintenance of physical and juridical data in the form of maps and lists, pertaining to fields, parcels of land, and apartment units.

One of the purposes of land registration is to ensure the legal certainty of property rights. Landowners can obtain legal certainty regarding their land rights by registering their property. The purpose of legal certainty regarding land rights is to provide legal protection to landowners (who owns it, whether or not it is burdened) and certainty about the object, specifically its location, boundaries, and extent, as well as the presence or absence of buildings and plants on it. ${ }^{4}$ Providing legal certainty in the land sector requires, first and foremost, the availability of comprehensive and clear written legal instruments that are consistently applied in accordance with the provisions' spirit and content. A certificate will be issued by the Land Office located in each Regency/City area for each land right that has been registered; the legal force of the certificate serves as strong evidence that, unless proven otherwise, the physical and juridical data listed in the certificate must be accepted as data. correct to the extent that the data contained in the letter of measurement and the land book are concerned. ${ }^{5}$

According to Civil Code Articles 1457, 1458, and 1459, the sale and purchase of land is an agreement in which one party agrees to surrender the land and the other party agrees to pay a predetermined price. When both parties reach an agreement, the sale and purchase are deemed to have occurred, even if the land has not been transferred or the price paid. However, even though the sale and purchase are considered to have occurred, the land rights have not yet been transferred to the buyer; therefore, another legal action, specifically in the form of a juridical transfer, is required to transfer the land rights from the seller to the buyer (transfer of name). This legal transfer (name change) aims to strengthen the buyer's rights as the new land owner. A contract, as defined in Article 1313 of the Civil Code, is an act by which one or more people bind themselves to another. A person's agreement with another person or persons results in a legal

${ }^{3}$ Lego Karjoko, Zaidah Nur Rosidah, and I Gusti Ayu Ketut Rahmi Handayani, 'Refleksi Paradigma Ilmu

Pengetahuan Bagi Pembangunan Hukum Pengadaan Tanah’, Bestuur, 7.1 (2019), 1-14 $<$ https://doi.org/10.20961/bestuur.v7i1.42694>.

${ }^{4}$ Bachtiar Effendie, Pendaftaran Tanah di Indonesia dan Peraturan-Peraturan Pelaksanaanya, Bandung, 1993, p 5

${ }^{5}$ Hilaire Tegnan, 'Legal Pluralism and Land Administration in West Sumatra: The Implementation of the Regulations of Both Local and Nagari Governments on Communal Land Tenure', Journal of Legal Pluralism and Unofficial Law, 47.2 (2015), 312-23 < https://doi.org/10.1080/07329113.2015.1072386>. 
DOI: https://doi.org/10.53955/jhcls.v1i2.12

Published by Lembaga Contrarius Indonesia

This work is licensed under a Creative Commons Attribution 4.0 International License (cc-by).

relationship called an engagement, and thus the agreement, in addition to other sources, is the source of the engagement. Wirjono Prodjodikoro defined an agreement as a legal relationship between two parties concerning property. When one party promises or is deemed to have promised to do or not to do something, and the other party has the right to insist on the fulfillment of the promise. ${ }^{6}$

A contract must be carried out in good faith; in the Civil Code, provisions regarding good faith, particularly those pertaining to the implementation of the contract, are found in Article 1338 paragraph 3, which states that all contracts must be carried out in good faith. This means that each party enters into an agreement in good faith, which includes a sale and purchase agreement in this case. Purchase and sale issues are inextricably linked to people's daily lives, and good faith in purchasing and selling is critical in ensuring that buyers with good intentions receive reasonable legal protection under applicable laws and regulations. The civil case 04/Pdt.G/2004/PN.END, in conjunction with the Kupang High Court Decision 74/Pdt/2005/Ptk, and the Supreme Court Decision $1758 \mathrm{~K} / \mathrm{Pdt} / 2006$, is the primary case involving the case of assets. inheritance, the following timeline summarizes the facts of the case: "Lay Nie Poe and Lio Keng Nyong have nine (nine) children in their marriage, two (two) sons and seven (seven) daughters, namely: Cahrles Ratu Lang (male) Defendant; Lay Fung Lang (female) Plaintiff 1; Lay Mei Lang (female) Plaintiff II; Lay Siu Kiang (male) Plaintiff III; Lay Juk Lan (female) Plaintiff IV; Lay Fuk Lan (female) Plaintiff. That the Plaintiffs' and Defendants' parents died in 1980, and that the Plaintiffs' and Defendants' father and mother died in 1998. Plaintiff and Defendant are a 180-square-meter plot of land and a two-story permanent shop house (Ruko) on Jalan Kemakmuran, Mbongawani Village, South Ende District, Ende Regency. The land is registered in the first child's name, alias the Defendant. ${ }^{7}$

According to the decision in the main case No. 04/Pdt.G/2004/PN.END, in conjunction with the Kupang High Court Decision No. 74/Pdt/2005/Ptk, and in conjunction with the Supreme Court of the Republic of Indonesia Decision No. $1758 \mathrm{~K} / \mathrm{Pdt} / 2006$, the Plaintiffs are the heirs to the subject of the dispute. In the main case No. 04/Pdt.G/2004/PN.END, the Plaintiff filed an application with the District Court seeking implementation of the decision 04/Pdt.G/2004/PN.END, and the District Court granted the request, issuing decision No. 04/Pdt.G/2004/PN.END. On July 24, 2010, the Defendant in Case 04/Pdt.G/PN.END entered into a sale and purchase transaction with Notary Clemens Nggotu, SH using Sale and Purchase Deed Number 45/ES/JB/IX/2011, and a Certificate of Ownership Number 00043 was issued on behalf of a third party (DONNY ROSANDY, ST). The sale and purchase of disputed land, as well as the issuance of certificates in the name of DONNY ROSANDY, ST, occurred following the Ende District Court Decision 04/Pdt.G/2004/PN.END, in conjunction with the Kupang High Court Decision 74/Pdt/2005/Ptk, and the Supreme Court of the Republic of Indonesia Decision $1758 \mathrm{~K} / \mathrm{Pdt} / 2006$ dated June 22, 2007, which has permanent legal force.

Then, in the case 04/Pdt.G/2004/PN.END, a resistance arose from the Defendant's side, in the case against the Number 06/Pdt.PLW/2013/PN.END, as the opponent to fight the litigant parties in the previous case in case 06/Pdt.PLW/2013/PN.END. The judge determined that the judge was incorrect in rejecting the Contestants' Resistance and declaring them to be Contestants. Finally, the Pelawan appealed to the Kupang High Court, whose case number was 26/Pdt/2014/PTK with the verdict, namely, the Kupang High Court Judge accepted the appeal

\footnotetext{
${ }^{6}$ R.Wirjono Prodjodikoro, Asas-asas Hukum Perjanjian, Mandar Maju, Bandung, 2000, p 9.

${ }^{7}$ Iswantoro, 'Strategy and Management of Dispute Resolution, Land Conflicts at the Land Office of Sleman Regency’, 1.1 (2021), 1-17.
} 
DOI: https://doi.org/10.53955/ihcls.v1i2.12

Published by Lembaga Contrarius Indonesia

This work is licensed under a Creative Commons Attribution 4.0 International License (cc-by).

from the Pelawan's original Appellant, annulling the Ende District Court's decision Number 06/Pdt.PLW/2013 /PN.END, declaring that the Pelawan was the legal owner of the plot of land and all the buildings that stood on it. Following the Kupang High Court Judge's appeal decision, the Defendant filed a cassation petition with the Supreme Court, but the Supreme Court Judge decided to deny the Cassation Petitioner's cassation request. ${ }^{8}$

\section{METHOD}

To address the issues raised in this paper, a method of normative juridical legal research using the statutory and case approach was used. Supported by primary legal materials in the form of applicable legislation in the form of Law No. 5 of 1960 on Basic Agrarian Regulations, Government Regulation No. 24 of 1997 on Land Registration, Ende District Court Decision No. 04/Pdt.G/2004/PN. END, Kupang High Court Decision No. 74/Pdt/2005/Ptk, and Supreme Court Decision No. $1758 \mathrm{~K} / \mathrm{Pdt} / 2006$, as well as secondary legal materials.

\section{Definition of Good Faith}

\section{RESULTS \& DISCUSSION}

According to Article 1338 of the Civil Code, all legally binding agreements are binding on those who enter them and must be carried out in good faith. Contract implementation in good faith refers to objective good faith. In good faith, the standard is objective and refers to an objective norm. The provisions relating to good faith refer to unwritten standards that have evolved into legal standards as a distinct source of law. These standards are said to be objective because they are not based on the parties' own assumptions, but rather on general assumptions about good faith.

Subekti defines good faith as someone who, when entering into an agreement with the opposing party that he believes is honest and does not conceal anything negative in the future, will cause future difficulties. Therefore, if it is associated with a buyer who has good intentions, a buyer who has good intentions is one who is unaware that he is dealing with someone who is not the owner. When the principle of good faith is violated in an agreement, the subjective and objective conditions for agreement validity as specified in Article 1320 of the Civil Code are not met, and the agreement must be declared non-binding and null and void. ${ }^{10}$

Buying and selling occurs frequently in society, resulting in a variety of complications, most notably in the sale and purchase of land, including the sale and purchase of land belonging to other people, where the seller is not the owner of the land or the seller is in default. In the Netherlands, this is referred to as wanprestie, which refers to the failure to perform the obligations set forth in the engagement, which includes both contractual and statutory obligations. Defaults are always the result of a contractual relationship. Contracts are created as instruments that regulate the legal relationship between private and civil interests, most notably in the context of contract formation. If the interests of individual communities in social life are violated, a conflict between rights and obligations will result. As a result of this method of buying and selling, the buyer who is honest and has good intentions will encounter difficulties in enjoying the goods he

\footnotetext{
${ }^{8}$ Syahlan, 'Effective and Efficient Synchronization in Harmonization of Regulations Indonesia', 1.1 (2021), $54-70$.

${ }^{9}$ Ridwan Khairandy, Itikad Baik dalam Kontrak di Berbagai Sistem Hukum, Jakarta, 2017, p 191

10 Abdul Kadir Jaelani and others, 'The Crime Of Damage After the Constitutional Court' s Decision Number 76 / PUU-XV / 2017', 1.1 (2021), 31-41.
} 
DOI: https://doi.org/10.53955/jhcls.v1i2.12

Published by Lembaga Contrarius Indonesia

This work is licensed under a Creative Commons Attribution 4.0 International License (cc-by).

purchases. One way to ascertain the buyer's good faith is to ascertain whether the buyer is aware that the land being purchased belongs to the seller. ${ }^{11}$

If the buyer truly believes that the seller is not the true owner of the land and thus does not have the right to sell it, the buyer can be said to have good intentions. A buyer with good intentions has the legal right to seek compensation from the seller. Indeed, there are views in the literature that divide the concept of good faith into two categories, subjective good faith and objective good faith.

a. Subjective good faith is a subset of the good faith principle, in which subjective good faith is linked to pre-contractual good faith. When parties negotiate, subjective good faith must exist. Subjective good faith is synonymous with honesty (honesty) and is referred to as such because it is predicated on the parties' honesty during the negotiation process.

b. Good Faith with a Purpose The term "objective good faith" refers to the process by which the standard or test is adjusted to the objective standard. Acting in good faith objectively refers to compliance with what the parties have rationally and properly agreed upon.

\section{An Examination of the Factors Considered by Judges in Determining Good Faith Ownership of Land Rights}

This thesis examines how judges decide cases involving the acquisition of land rights in good faith. The purpose of this research is to examine the factors considered by a panel of judges when deciding cases involving the acquisition of land rights in good faith, beginning with the first court level and continuing through the Supreme Court's review of Supreme Court Decision 1758 $\mathrm{K} / \mathrm{Pdt} / 2006$. He granted the Plaintiff's claim in its entirety in his consideration of the main case number 04/Pdt.G/2004/PN.END, in conjunction with the Kupang High Court Decision number 74/Pdt/2005/PTK, and in conjunction with the Supreme Court Decision number 1758 $\mathrm{K} / \mathrm{Pdt} / 2006$. and establish legally that the heirs, namely the Plaintiffs and Defendants, have equal rights to the assets inherited by their parents. ${ }^{12}$

The Panel of Judges determined that the subject of the dispute, a plot of land and building, is an inheritance from the Plaintiffs' parents, as is the distribution of joint rights made before a Notary. In comparison to the Civil Code, the author believes that Law No. 5 of 1960 on Basic Agrarian Principles and its implementing regulations, Government Regulation No. 24 of 1997 on Land Registration, are appropriate because the Panel of Judges provides considerations based on evidence and facts revealed in court. Among the judge's considerations are the following:

1. In accordance with the decision in case 74/Pdt/2005/PTK, the Judge of the High Court made legal findings based on the documents of evidence submitted by both parties in this case. After a thorough examination by the Panel of Judges, the High Court ruled in favor of the Plaintiffs as heirs to the disputed property. The High Court Judge's comparison of Article 164 HIR and Article 1866 of the Civil Code to the decision No. 74/Pdt/2005/PTK is appropriate, because the High Court Judge's legal analysis is based on the evidence file from both parties to the case, and the evidence is based on Article 164 HIR and Article 1866 of the Civil Code, which regulate evidence.

${ }^{11}$ Arifin Ma'ruf, 'Legal Aspects of Environment in Indonesia : An Efforts to Prevent Environmental Damage and Pollution', 1.1 (2021), 18-30.

12 Iswantoro. 
DOI: https://doi.org/10.53955/ihcls.v1i2.12

Published by Lembaga Contrarius Indonesia

This work is licensed under a Creative Commons Attribution 4.0 International License (cc-by).

2. 2. Consideration of Cassation Decision No. $1758 \mathrm{~K} / \mathrm{Pdt} / 2006$ demonstrates that the Cassation Petitioner's objection cannot be justified, because the Judex Facti or the Panel of Judges at the first level, in this case the Ende District Court, that examined the evidence in the case did not misapply the law regarding the assessment of the results of the evidence that is favorable to the case. The fact cannot be considered in the Cassation level examination, as the Cassation level examination is limited to violations of the applicable law. Based on the foregoing, it appears that the Judex Facti decision in this case does not contradict the law or the Act, and thus the Cassation Petitioner's Cassation application must be denied. When compared to Law No. 14 of 1985 concerning the Supreme Court, Law No. 5 of 2004 concerning Amendments to Law No. 14 of 1985 concerning the Supreme Court, and Law No. 3 of 2009 concerning the Second Amendment to Law No. 14 of 1985 concerning the Supreme Court Article 30 paragraph (1), the Supreme Court's considerations are appropriate.

3. Considerations for judges in the event of resistance 06/Pdt.PLW/2013/PN.END.

Rejecting the Contestants' Complete Resistance.

- Given that the dispute over the object of the dispute was resolved in the Ende District Court Decision 04/Pdt.G/2004/PN.END, in conjunction with the Kupang High Court Decision 74/Pdt/2005/PTK, and in conjunction with the Supreme Court Decision RI number: 1758 K/Pdt/2006 on June 22, 2007, which upheld the First Level Decision in the Appeal Decision and by the Supreme Court state.

- Consider that, while the disputed object land is stated in the Decision Number: 04/Pdt.G/2004/PN.END to be divided equally between the Plaintiffs and Defendants, namely 1/9 each, on September 30, 2011, the land and building on it (the subject of the dispute) were sold by the Opponent (aka Charles Ratu Mite) to the Pelawan pursuant to the Sale and Purchase Deed No. 45/ES/JB/IX/20.

- Given that the Opponent's action to sell the object of dispute to the Opponent occurs without the consent of the other heirs who both have legal rights to the disputed land and building on it, the Panel of Judges believes that in this case, the sale of an inheritance that has not been divided must be approved by all heirs, while the sale of a divided inheritance must be approved by all heirs. If this type of sale and purchase continues, it must be declared null and void due to the absence of a lawful reason, which is one of the object requirements for an agreement's validity (Article $1320 \mathrm{BW}$ ).

- Given that the Sale and Purchase Deed No. 45/ES/JB/IX/2011 lacks legal force, the letters or documents by and on behalf of the Pelawan regarding disputed land ownership are not legally enforceable.

- Taking this into consideration, the Panel of Judges will then determine whether the Defendant is a bona fide purchaser.

- Given that the process of purchasing and selling disputed land, as well as the issuance of certificates in the name of the Pelawan, occurred following the Ende District Court Decision, the Panel of Judges determined that, at the time of the sale and purchase agreement and the issuance of certificates, the disputed parcels of land were in a state of dispute due to the fact that the disputed land is. 
DOI: https://doi.org/10.53955/jhcls.v1i2.12

Published by Lembaga Contrarius Indonesia

This work is licensed under a Creative Commons Attribution 4.0 International License (cc-by).

- Considering that, pursuant to Article 39 paragraph (1) f of Government Regulation No. 24 of 1997 on Land Registration, a PPAT/Notary should refuse to execute a deed of sale and purchase if the subject of the sale and purchase is disputed.

- Consider that, pursuant to the provisions of Article 45 paragraph (1) e of Government Regulation Number: 24 of 1997 concerning Land Registration, the Head of the Land Office of Ende Regency should refuse to register the transfer of rights from the Opponent to the Opponent because the registration object is disputed in court.

4. Review of Appeal Decision No. 26/Pdt/2014/PTK. The legal considerations based on evidence from both parties which stated that the opponent was an opponent who did not have good intentions, after being studied carefully by the Panel of Judges of the High Court, it turned out that the panel of judges found new things, namely the opponent did not know that the object of the dispute was still in the process in court and grant the petition of the opponent as a buyer in good faith, as well as the owner of a plot of land and buildings standing on it in accordance with the evidence of SHM No. 00043.

5. Review of Cassation Decision No. $2701 \mathrm{~K} / \mathrm{Pdt} / 2014$. The objection of the Cassation Petitioner cannot be justified because the Cassation Petitioner states that the Opponent is a buyer who does not have good intentions and therefore rejects the Cassation Application and decides that the Petitioner is a buyer with good intentions. According to this second case decision, because the buyer is a buyer with good intentions, the buyer may assert his rights against the seller in accordance with the terms of the mutually agreed-upon agreement. If one of the parties fails to perform the obligations set forth in the sale-purchase agreement, the other party may seek compensation under the provisions of Article 1267 of the Civil Code:

"The party to whom the agreement is not fulfilled has a choice: he can either force the other party to fulfill the agreement, if that is still possible, or he can demand cancellation of the agreement, along with reimbursement of costs, losses, and interest."

Thus, the author asserts, the legal owner of the case land is the inheritance land, which cannot be traded without the consent of the other heirs, due to the fact that one of the heirs sold a certificate that is no longer valid, as the certificate was canceled by the Court Judge. Agung no. $1758 \mathrm{~K} / \mathrm{Pdt} / 2006$ and stated that the dispute concerned inheritance. Thus, the seller's sale of the disputed item is null and void because it violates the legal requirements of an agreement. The buyer must then seek compensation from the seller.

\section{The Authority of Land Certificates as Evidence of Rights}

According to Article 19 paragraph (2) letter c of the LoGA, the end of the government's land registration activities is the provision of a certificate of proof of rights, which serves as strong evidence. The UUPA makes no reference to the registered land rights certificate's name. Only in Article 13 paragraph (3) of Government Regulation no. 10 of 1961 it is stated that the certificate of proof of registered land rights is called a certificate, which is a copy of the land book and measuring document after being sewn together with a cover paper whose shape is determined by the Minister of Agrarian Affairs. In Government Regulations No. 40 of 1996 and No. 24 of 1997, there are several certificates based on the purpose of land registration, namely:

a. Ownership Certificate. 
ISSN (Print) 2807-2979, ISSN (Online) 2807-2812

DOI: https://doi.org/10.53955/ihcls.v1i2.12

Published by Lembaga Contrarius Indonesia

This work is licensed under a Creative Commons Attribution 4.0 International License (cc-by).

b. Certificate of Cultivation Rights.

c. certificate for state land of Hak Guna Bangunan

d. Certificate of Right to Build on Managed Land.

e. A certificate of right of use for state-owned property.

f. Land Use Right of Management Certificate.

g. Certificate of Management Rights for Land.

h. Certificate of Waqf land.

i. Flat Unit Certificates of Ownership.

j. Ownership Certificates for Non-Condominium Units.

k. Certificate of Mortgage

The LoGA specifies the nature of proof of certificate as proof of rights in Article 19 paragraph (2) letter c. To be specific, a certificate serves as a strong evidence tool, and the physical and juridical data contained in the certificate are presumed to be correct as long as they are not contradicted by other evidence, which may be in the form of a certificate or something else. Depending on the nature of this evidence, the party who feels aggrieved by the certificate's issuance may file a lawsuit in court to have the certificate declared invalid. If the court's decision declaring the certificate invalid has permanent legal effect, the Head of the National Land Agency of the Republic of Indonesia issues a decree canceling the certificate.

The nature of a certificate as a proof of rights is defined in Article 32 of Government Regulation No. 24 of 1997, as follows: (1) A certificate is a letter of proof of rights that serves as a strong means of proof in relation to the physical and juridical data contained therein, provided that the physical and juridical data are consistent with the data contained in the letter of measurement. (2) If a land parcel has been legally issued in the name of the person or legal entity that acquired it in good faith and clearly has control over it, the other party who believes he or she has rights to the land may no longer demand the exercise of those rights if the other party does not file a written objection to the certificate within five (five) years of the certificate's issuance.

\section{Legal Protection for Good-Intentioned Buyers}

Buying and selling, as defined in Article 1457 of the Civil Code, entails an agreement. According to Article 1320 of the Civil Code, the conditions for the validity of an agreement are the consent of those who bind themselves, the ability to enter into an engagement, the existence of a specific thing, and a lawful cause. If the conditions relating to the agreement and skills (subjective conditions) are not met, the agreement may be canceled, which means it will remain in effect until a judge makes a decision. ${ }^{13}$ Meanwhile, if the conditions pertaining to a particular matter and a lawful cause (objective conditions) are not met, an agreement is null and void, implying that there is no agreement at all. According to Abdulkadir Muhamad, buying and selling is a transaction in which the seller transfers ownership of the goods to the buyer in exchange for a specified sum of money. From the foregoing, it can be concluded that what is referred to as buying and selling must satisfy several criteria:

a. There is a reciprocal agreement;

b. An item is transferred from one party (the seller) to another; and c. The buyer pays a price in exchange for acquiring property rights.

13 Muhammad Jihadul Hayat, 'Historisitas Dan Tujuan Usia Minimal Perkawinan Dalam PerundangUndangan Keluarga Muslim Indonesia Dan Negara Muslim’, Journal Equitable, 3.1 (2018), 49-63. 
DOI: https://doi.org/10.53955/jhcls.v1i2.12

Published by Lembaga Contrarius Indonesia

This work is licensed under a Creative Commons Attribution 4.0 International License (cc-by).

According to Article 1320 of the Civil Code, an agreement must satisfy four conditions in order to be valid, namely:

1) Agree with those who bind themselves;

2) The capacity to make an agreement;

3) A particular thing; and

4) A lawful cause / cause.

The first two conditions pertain to the subject (subjective conditions), whereas the final two conditions pertain to the object's knowledge (objective requirements). A contract with a defect in the subject does not always render the contract null and void on its own, but frequently only allows for cancellation, whereas a contract with a defect in the object is null and void. The Civil Code's covenant law is based on the principle of consensualism, or agreement. Covenant law is based on the principle that it is sufficient to agree to give birth to an agreement, and that the agreement is born at the time or seconds of agreement with the engagement in the agreement. Each agreement must be carried out in good faith, as specified in Article 1338(3) of the Civil Code. In Indonesia, good faith is regulated by Article 1338 paragraph (3) of the Civil Code, which states that "a contract must be carried out in good faith." Because law-abiding purchasers have a right to legal protection, justice, and legal certainty.

In addressing this research question, how is legal protection provided for buyers with good intentions (case study: Supreme Court Decision 1758 K/Pdt/2006), which states that the object being traded is an inheritance with permanent legal force and may not be sold? purchase it without the consent of the other heirs, the author deduces from the verdict that one of the heirs sells the subject of the dispute to the buyer without the other heirs' consent. The agreement between one of the heirs and the buyer can be concluded to be invalid and null and void. A valid agreement is one that complies with the provisions of Article 1320 of the Civil Code. This is an absolute requirement that must be met in order for an agreement to be considered valid. The first and second conditions are subjective in nature, as they pertain to the parties or subjects to the agreement. If these two conditions are not met, the agreement can be canceled, which means that the agreement remains valid as long as the parties do not cancel it through the courts. The third and fourth conditions, on the other hand, are objective conditions because they pertain to the agreement itself or the subject of the legal action. If the final two conditions are not met, the agreement is null and void, implying that there was never an agreement in the first place. When you enter into an agreement, you must adhere to the agreement's law and not violate the applicable law. ${ }^{14}$

In light of the legal issues under consideration, the sale and purchase agreement for inheritance land does not comply with the legal requirements for an agreement set forth in Article 1320 of the Civil Code. The buyer in the case at hand is unaware that the land he has purchased is an inherited property with permanent legal force that should not be traded without the consent of other heirs. A sale and purchase agreement must be drafted in good faith, bearing in mind that buying and selling is an agreement between parties to bind themselves to hand over an object to another party. Thus, the principle of good faith is critical for avoiding concealed defects in traded goods. As stated in article 1491 of the Civil Code, "the seller's obligation to the buyer is to ensure two things: first, control of the object being sold safely and peacefully, and second, against

${ }^{14}$ Isharyanto Bahar Elfudllatsani and Agus Riwanto, 'Kajian Mengenai Kebebasan Berkumpul Dan Berserikat Organisasi Kemasyarakatan Kaitannya Dengan Teori Kedaulatan Rakyat Dan Hak Asasi Manusia', Jurnal Pasca Sarjana Hukum UNS, VII.1 (2019), 52-61. 
DOI: https://doi.org/10.53955/ihcls.v1i2.12

Published by Lembaga Contrarius Indonesia

This work is licensed under a Creative Commons Attribution 4.0 International License (cc-by).

concealed defects in the goods, or in such a way as to give grounds for cancellation of the purchase."

According to this article, the seller's obligation is to safeguard the goods he wishes to sell from harmful disturbances and to explain critical information to the buyer so that, in the event of a dispute over the object of sale and purchase, the buyer is not harmed. Not only the seller must have good intentions when selling an item; both parties, specifically the buyer, are also required to act in good faith by inspecting the item for hidden defects prior to making a purchase. As stated in article 1338 paragraph 3, an agreement must be made in good faith by both parties, which means that any sale and purchase agreement made in good faith must adhere to the agreement's substance on the basis of mutual trust. However, if one of the parties is found to have acted in bad faith during the negotiation or implementation of the agreement, the party with good intentions will receive legal protection. ${ }^{15}$

The land sold to the buyer is not his personal property, but is jointly owned by the other heirs. When the seller claimed that the land was his and then sold it to the buyer, there was a fraud because the seller provided false information that was inconsistent with the actual facts, accompanied by deception. Thus, if the seller's manufacture or performance of the agreement is determined to be in bad faith, the party with good intentions, namely the buyer, must obtain legal protection. The author then examines the major issues concerning legal protection for buyers in the case of buying and selling inheritance land using legal protection theory. As previously stated, legal protection can be classified as preventive or repressive.

The government provides preventive legal protection prior to the occurrence of a violation specified in a statutory regulation by erecting signs or imposing restrictions on the performance of a legal act. The seller in this case abused his authority by selling inherited land that carries permanent legal force and should not be traded, while the buyer in this case is unaware that the land that he purchased is actually inherited land, necessitating legal protection for the buyer. Multiple articles of legislation provide legal protection for buyers with good intentions when purchasing and selling inheritance land, as it clearly contains elements of error and fraud. Article 1491 of the Civil Code provides protection in the form of guarantees, which state that: "The insurance that is the seller's obligation to the buyer is to guarantee two things: first, the safe and secure control of the goods being sold; and second, the existence of hidden defects in the goods, or in such a way as to constitute grounds for canceling the purchase."

\section{CONCLUSION}

The legal protection accorded to the holder of a certificate of title to land in good faith is not applicable to the Defendant (Suwarjito) as the holder of certificate of title to land No. 2129. As provided for in Article 32 of Government Regulation No. 24/1997, the holder of a certificate of ownership may be granted guarantees and legal protection. who are in control of good intentions, and no other party believes they have the right to challenge these rights. According to Article 1471 of the Civil Code, the sale and purchase agreement is void because the object traded is not the seller's property; therefore, the buyer should vacate and surrender the land voluntarily to the original owner, and seek accountability by requiring the seller to return it through the courts. the amount of money he paid to purchase the land, plus all associated costs, losses, and interest. Although the procedure for purchasing and selling land was carried out in accordance

15 Yunirman Rijan dan Ira Koesoemawati, Cara Mudah Membuat Surat Perjanjian/Kontrak dan Surat Penting Lainnya, Raih Asa Sukses, Jakarta, 2009, p. 8. 
DOI: https://doi.org/10.53955/jhcls.v1i2.12

Published by Lembaga Contrarius Indonesia

This work is licensed under a Creative Commons Attribution 4.0 International License (cc-by).

with the provisions of Article 37 paragraph (1) PP No. 24 of 1997 and was registered with the National Land Agency prior to PPAT, the sale and purchase agreement is void under the provisions of Article 1471 of the Civil Code because the object being traded is not property.

\section{REFERENCES}

A.P Parlindungan, (1999), Pendaftaran Tanah di Indonesia (Berdasarkan PP 24 Tahun 1997) Dilengkapi dengan Peraturan Jabatan Pejabat Pembuat Akta Tanah (PP 37 Tahun 1998) :

Abdulkadir Muhammad, Hukum Perikatan, cetakan ke-3, Citra Aditya Bakti, Bandung , (2010), Hukum Perjanjian, PT Alumni, Bandung

Bahar Elfudllatsani, Isharyanto, and Agus Riwanto, 'Kajian Mengenai Kebebasan Berkumpul Dan Berserikat Organisasi Kemasyarakatan Kaitannya Dengan Teori Kedaulatan Rakyat Dan Hak Asasi Manusia', Jurnal Pasca Sarjana Hukum UNS, VII.1 (2019), 52-61

Hayat, Muhammad Jihadul, 'Historisitas Dan Tujuan Usia Minimal Perkawinan Dalam Perundang-Undangan Keluarga Muslim Indonesia Dan Negara Muslim', Journal Equitable, 3.1 (2018), 49-63

Iswantoro, 'Strategy and Management of Dispute Resolution, Land Conflicts at the Land Office of Sleman Regency', 1.1 (2021), 1-17

Jaelani, Abdul Kadir, Universitas Sebelas Maret, Resti Dian Luthviati, Civil Registration, Study Program, and Universitas Sebelas Maret, 'The Crime Of Damage After the Constitutional Court 's Decision Number 76 / PUU-XV / 2017', 1.1 (2021), 31-41

Karjoko, Lego, Zaidah Nur Rosidah, and I Gusti Ayu Ketut Rahmi Handayani, 'Refleksi Paradigma Ilmu Pengetahuan Bagi Pembangunan Hukum Pengadaan Tanah', Bestuur, 7.1 (2019), 1-14 < https://doi.org/10.20961/bestuur.v7i1.42694>

Ma'ruf, Arifin, 'Legal Aspects of Environment in Indonesia: An Efforts to Prevent Environmental Damage and Pollution', 1.1 (2021), 18-30

Res, Redi, 'Implementation of Parate Executie Object of Liability Juridical Overview of Mortgage', 1.1 (2021), 42-53

Syahlan, 'Effective and Efficient Synchronization in Harmonization of Regulations Indonesia', 1.1 (2021), 54-70

Tegnan, Hilaire, 'Legal Pluralism and Land Administration in West Sumatra: The Implementation of the Regulations of Both Local and Nagari Governments on Communal Land Tenure', Journal of Legal Pluralism and Unofficial Law, 47.2 (2015), 312-23 <https://doi.org/10.1080/07329113.2015.1072386>

Bachtiar Effendie, (1993), Pendaftaran Tanah di Indonesia dan Peraturan-Perturan Pelaksaanya, Bandung

Budi Harsono, (2002), Hukum Agraria Indonesia ( Himpunan Peraturan-Peraturan Hukum Tanah ), Cetakan Kelimabelas, Edisi Revisi : Jakarta, Djambatan

M.P Siahan, (2003), Bea Perolehan Hak Atas Tanah dan Bangunan Teori dan Praktek, Jakarta: Raja Grafindo Persada

R.WirjonoProdjodikoro, (2000), Asas-asas Hukum Perjanjian, Mandar Maju, Bandung, (selanjutnya disingkat R. WirjonoProdjodikoro I)

Ridwan Khairandy,(2017) Itikad Baik dalam Kontrak di Berbagai Sistem Hukum, Jakarta

R. Subekti, Aneka Perjanjian, PT. Aditya Bakti, Bandung

Yunirman Rijan dan Ira Koesoemawati, (2009), Cara Mudah Membuat Surat Perjanjian/Kontrak dan Surat Penting Lainnya, Raih Asa Sukses, Jakarta 
$134 \quad$ Journal of Human Rights, Culture and Legal System, Volume 1, No. 2, 2021 ISSN (Print) 2807-2979, ISSN (Online) 2807-2812

DOI: https://doi.org/10.53955/ihcls.v1i2.12

Published by Lembaga Contrarius Indonesia

This work is licensed under a Creative Commons Attribution 4.0 International License (cc-by).

Nomor 04/Pdt.G/2004/PN.END jo Putusan Pengadilan Tinggi Kupang Nomor 74/Pdt/2005//Ptk, jo Putusan Mahkamah Agung RI Nomor 1758 K/Pdt/2006 